MUCOSAL MAST CELLS IN THE BABY RAT JEJUNUM Verkasalo M. Forguson A, Mller HRP, Cummins A. Gastro.Intestinal Unit, Western General Hospital.

University of Edinburgh. and Moredun Research Institute, Edinburgh, Scotland, UK.

Mucosal mast cells (MMC) are found mainly within the jejunal submucosa. MMC increase in intestinal graft-versus-host reaction, and their degranulation is observed in parastic enteropathy. Weaning is assoclated with morphological changes resemin parasitic enteropathy. Weaning is assoclated with morphological changes resem-
bling those seen in mild cell-mediated intestinal injury. We studied MMC in the bling those seen in mild cell-mediated inlestinal injury. We studied MMC in the
young rat jejunum in relation to weaning changes. Jejunal morphology, crypt cell young rat jejunum in relation to weaning changes. Jejunal morphology, crypt cell
production rate, intraopithelial lymphocytos (IEL) and goblet colls woro studied, and MMC were counted in rat mast cell protease II antibody (anti-RMCP II) and toluidine blue stained sections. Serum RMCP II was delermined with a direct ELISA method. In the next few days following weaning the jejunal villi shortened by about $30 \%$, crypts elongaled by the same amount, cypt cell production rate more than doubled, and the numbers of IEL showed a marked increase. The MMC counts showed a steady increase trom birth to the time of weaning. sharp fall on the iwo days immediately after weaning, and further increase the reafter. Serum RMCP II level displayed a sudden tise at the time of weaning, with gradual decline thereafter. Mucosal mast cell degranulation, obviously as socialed with the evert of weaning, may be responsible for the observed morphological changes through epithelial cell damage. Weaning is a period of temporary loss of oral tolerance in rats; this might be a result of fejunal injury caused by mucosal mast cell protease.

IN MICE, GLUTEN IN MATERNAL DIET PRIMES SYSTEMIC IMMUNE RESPONSES TO GLIADIN IN OFFSPRING

\title{
R.Troncone, A.Ferguson
}

Gastro-Intestinal Unit, University of Edinburgh and Western General Hospital, Edinburgh, Scotland, UK

Mice reared on a gluten-containing diet (GCD) are immunologically tolerant to giladin (1). Aim of this study was to investigate whether oral tolerance is recreated in each generation by the ingestion of dietary gluten at weaning, or whether it is transferred from mother to young (as immune status or via passage of antigen) before birth or during lactation.

$B A L B / c$ mice were used, reared on a gluten-free diet (GFD), born to mothers either from a GFD or a GCD colony. After parenteral immunisation with gliadin, both humoral and cell-mediated immunity were assessed by serum antibody (ELISA) and footpad swelling test, respectively.

Unexpectedly, mice born to mothers from a $C C D$ colony showed systemic immune responses to gliadin significantly higher $(p<0.05)$ than gice born to mothers from a GFD colony. Furthermore, feeding mothers GCD for defined periods before and during pregnancy and during lactation, also resulted in priming of the specific immune responses of the of fspring.

These findings indicate that, in mice, sensitisation to maternal dietary antigens occurs in utero or shortly after b1rth. This animal model should allow Investigation of the immunological mechanisms concerned.

(1) Troncone R, Ferguson A. Immunological properties of gliadin presented via the gut. 20th Annual Meeting of ESPGAN, Lisbon 1987.

6 Gioulet $O$, Revillon $Y$,Cerf-Bensussan $N$, Nezelof $C$,Jan $D$ Pellerin D, Ricour C.

Hopital des Enfants Malades Paris France.

After an experimental stage on piglets small intestine transplantation(SIT)using Cyclosporine $\mathrm{A}(\mathrm{CsA})$ we now report a human case. 9 yrs old girl, on home parenteral nutrition for short small bowel (volvulus)for 6 yrs was transplanted with $120 \mathrm{~cm}$ small intestine harvested by an isoblood group A 17 yrs old boy pronouced brain dead.Cross match reaction donor and recipient was negative.After aorta and inferior vena cava anastomosis total ischemic time was $3 \mathrm{~h} 55 \mathrm{mn}$; both graft and own intestine were exteriorized as stomas Immunosuppression included solumedrol $2 \mathrm{mg} / \mathrm{kg} / \mathrm{d}$ and $\mathrm{CsA}$ as a continuous infusion to maintain serum levels between 200-300 $\mu \mathrm{g} / 1$. Acut graft rejection(GR)occured on day 13 marked only with an increase ileostomy drainage; histologic pattern included progressively=vill oedema, Tcell infiltrates $\left(\mathrm{CD}^{+} / \mathrm{CDB}^{+}\right.$), increased HLADR expression by enterocytes, observed.The course after GR was marked with a persistant protein losing enteropathy up to a progressive intestine recovery as show by repeated histologic findings, baryum transit(day 30 and 80 ) and start oral feeding from day 60 . Unfortunately from the $6^{\circ}$ month the addition of prolonged CsA IV administration, long term PN and probable viral infection induced severe liver disease and hematologic disorders requiring graft removal after $6 \frac{1}{2}$ months.The patient died.This course demonstrate that 6 months survival is possible after SIT Smal bowel recovery can be achieved despite extensive mucosal destruction caused be acute grart rejection.

7 COMPARISON OF RETICULIN (ARA) AND ENDOMYSIUM
(EMA) ANTIBODIES IN COELIAC DISEASE.

Mäki M, Hällströ̀ O, Polanco I, Visakorpi JK.

Departments of Microbiology and Paediatrics, University Central Hospital of Tampere, Finland and Hospital Infantil "La Paz", Madrid, Spain

IgA class ARA and EMA are both suggested to be good indicators of villous atrophy in coeliac disease (CD). We have now done the tests parallelly in children with untreated $C D$ (52), on gluten-free diet (20) and during gluten challenge (10). Children (50) biopsied because of suspected $C D$ and with normal mucosa served as controls. Furthermore 100 adult blood donors were tested. Children with untreated CD were both ARA and EMA positive (titres $1: 10$ to $1: 8000$ for both). 5 children with IgA deficiency and flat intestinal mucosa were negative for both deficiency and flat intestinal mucosa were negative for both tests. During gluten-free diet disappearance of both ARA and
EMA correlated well with mucosal recovery. 4 children with EMA correlated well with mucosal recovery. 4 children with normal mucosa were found to have these antibodies in titres
$1: 5$ to $1: 200$. They all were brothers and sisters to CD patients. All the others were ARA and EMA negative. One of the blood donors was positive for both tests. On biopsy, subtotal villous atrophy was found. The absorption of antibodies from patient sera with animal and human tissues and retesting results sugeest the antigens for ARA and BMA not to be fully identical. However, in clinical practise no difference between identical. However, in clinis
9 INTESTINAL CELL MEDIATED IMMUNity (CMI) TO GLIADIN IS INDUCED IN MICE BY PARENTERAL IMMUNISATION AND CONCURRENT GRAFT-VERSUS-HOST (GVH) REACTION. R.Troncone, A.Ferguson

Gastro-Intestinal Unit, University of Edinburgh and Western General

Hospital, Edinburgh, Scotland, UK

Mucosal CMI to gliadin is likely to be 1mplicated in the pathogenesis of coeliac disease. Our aim was to induce mucosal CMI to gliadin by feeding gluten-containing diet (GCD) to mice previously parenterally immunised with this antigen.

BALB/c mice from a gluten-free diet (GFD) colony were used. They were given parenterally giladin in complete Freund's adjuvant, and 3 weeks later they were challenged with GCD for 7 days. In further experiments the ef fect of concurrent GVH reaction was evaluated in BDF1 mice on a CCD, previously immunised with gliadin. CMI responses in small intestinal mucosa were measured by morphometry (villous and crypt length, crypt cell production rate (CCPR), and intraepithellal lymphocytes (IEL) count).

Feeding GCD for a week to mice reared on GFD did not produce any change. Similarly, mice given GCD after having been parenterally immised with gliadin did not show mucosal CMI. Mice on GCD given both gliadin immunisation and GVH showed a significant increase $(p<0.05)$ in crypt depth, CCPR and IEL count, in comparison to controls given only GVH.

These results indicate that systemic imnunity to gliadin is not sufficient to Induce specific intestinal CMI. Additional factors (enhanced antigen presentation, increased intestinal permeability) are also necessary.
AN HLA-DQ ALPHA ALLELE IDENTIFIED AT DNA AND PROTEIN LEVEL IS STRONGLY ASSOCIATED WITH COELIAC DISEASE B.0. Roep, R.E. Bontrop, A.S. Peña*, M.C.J.A. van Eggermond, J.J. van Rood and M.J, Giphart.

Depts, of Immunohaematology and Blood Bank and *Gastroenterology, University Hospital, Leiden, The Netherlands.

Susceptibility genes for coellac disease are assoclated with certain HLA-DR genotypes. More recent studies also show strong assocfation with some HLA-DQ alleles. We have examined the presence of disease associated HLA-DQ alleles by restriction fragment length polymorph1sm (RFPL) with the help of a HLA-DQ alpha cDNA probe. This probe showed upon hybridization a highly significant discrepancy between the RMP of coellac disease significant discrepancy between the RFLP of coellac disease patients and healthy controls. The $4.0 \mathrm{~kb}$. Bgl II restriction fragment was present in $97 \%$ of coeliac disease patients $(n=30)$, compared to pre in a healthy control population (n-72) (RR$14.9 ; p<0.0005)$. Th1s fragment 18 associated with HLA-DR3, -5 ,
some DRw8, and DRw14Dwl6. Th1s was confirmed by the analysis of some DRw8, and DRw14Dwl6. Th1s was confirmed by the analysis of the panel of 72 homozygous typing cells obta1ned from At the product level all coellac disease patients tested sofar have one DQ alpha chain in common, designated HLA-DQ alpha 2.3, which is associated with the $4.0 \mathrm{~kb} B g 1$ II fragment. This HLA-DQ alpha allele 1dentffied at the DNA level and product level seems to be a better marker for genetic susceptibility to develop coeliac disease than those available sofar. 